\title{
A study on the comparative growth performance of three genotypes of ducklings with or without supplementary feeding in coastal areas of Bangladesh
}

\author{
M.M. Rahman ${ }^{1 *}$, M.J. Khan ${ }^{2}$ and S.D. Chowdhury ${ }^{3}$ \\ ${ }^{1}$ District Livestock Officer, Department of Livestock Services, Rajshahi. ${ }^{2}$ Professor, Department of \\ Animal Nutrition, Bangladesh Agricultural University, Mymensingh-2202. ${ }^{3}$ Professor, Department of \\ Poultry Science, Bangladesh Agricultural University, Mymensingh-2202, Bangladesh
}

\begin{abstract}
An experiment was conducted with Muscovy, Pekin and Desi white ducklings for a period of 98 days in three villages of Noakhali district in order to know the effect of feed supplementation on growth performance and cost of production under scavenging system of rearing. A factorial experiment $(2 \times 3)$ was designed for 2 feeding regimes (control and supplemented) and 3 genotypes of duck. The feed supplements consisting of a mixture of rice polish, broken rice and wheat bran @ 90,30 and 20\% respectively. At 98 days of age, final hive weight, live weight gain, feed conversion efficiency and survivability were highest in Muscovy and lowest in Desi white irrespective of feeding regimes. The differences among the genotypes were statistically significant $(\mathrm{P}<0.01)$ for final live weight and live weight grain. Feed conversion ratio was better in Muscovy than in Pekin and Desi white. The profit margin (Tk. 68.31 vs 16.96) and cost benefit ratio (2.38 vs 1.38) were highest for Muscovy and lowest for Desi white ducklings. Feed had a significant $(\mathrm{P}<0.01)$ effect on total cost and genotypes also showed significant effect $(\mathrm{P}<0.0)$ on total cost. The profit margin differed significantly among the genotypes of bird and feeding regimes. From the study, it may be concluded that Muscovy ducklings could be profitably reared through supplementary feeding of $60 \mathrm{~g}$ concentrate mixture daily under scavenging system in the rural areas and should be marketed at the age of 6 weeks.
\end{abstract}

(Key words: Scavenging ducklings, feed supplementation, growth performance and coastal areas)

\section{Introduction}

Duck production has contributed a considerable amount of income for farmers of rural households in the coastal areas of Bangladesh. Three genotypes of ducks were raised in these areas and they were Desi, Pekin and Muscovy. Muscovy ducks reared under scavenging system and showed a great potential for income generation of poor farmers when supplemental feeds from local feed resources are fed (Dong, 1996). Some recent studies indicated that Muscovy ducks also showed good performance when fed on cereal based concentrates (Dong and Phuoc, 1994; Phuoc et. al., 1994). However, limited information is available on their performance under village conditions. Muscovy, a meat-type duck, has lower fertility and hatchability but excellent for

*Corresponding author: dlorajshahi@yahoo.com

Bang. J. Livs. Res. Vol. 20 ( 1 \& 2), 2013: P. 33-41, ISSN 1022-3851 
small farmers as they are very good foragers and can raise their own young (Klemn and Pingel, 1992; Ahmed, 1986). Pekin is also an excellent meat producing duck but has poor scavenging ability and high mortality under village conditions (Ahmed, 1986). Muscovy and Pekin ducks are becoming more popular in hotel and restaurants. Desi ducks, though small in size, are well adapted to management in rural conditions of Bangladesh (Khan, 1983) and their meat yield has been reported to be excellent (Ahmed, 1986). Desi ducks not only make a major proportion of total duck population in Bangladesh but also contribute significantly in meeting the demand of people for egg and meat. Recently, many people in the low-lying areas have started to rear ducks of different genotypes with locally available feedstuffs under scavenging condition. Ducks are not only more resistant to diseases as compared to chickens but also they lay larger eggs and supply more meat than indigenous chickens and ranks second to chicken in total egg production (Ahmed, 1986). According to BBS (2010) average per capital availability of meat is $19.00 \mathrm{~g}$ against the requirement of $120 \mathrm{~g} /$ day. The supply and demand gap of the animal protein can be met by increasing the production of duck meat and eggs. The people of the coastal areas of Bangladesh are very much interested to raise ducks than chicken. Duck rearing would increase the employment opportunity as well as subsidiary income of the rural women, landless and marginal farmers. Exotic ducks like Muscovy, Pekin along with Desi white are very popular for commercial meat production under scavenging conditions. Traditionally the ducks are reared on scavenging with some feed supplementation but results have been disappointing because of imbalanced use of available supplements (Hoque et. al., 2001). So, the purpose of the present study was to demonstrate better ways of using the locally available feed supplements in order to take advantage of the higher growth potential of Muscovy, Pekin and Desi ducks and to work out a level of supplementation that would keep production cost to a minimum under scavenging condition in coastal areas of Bangladesh.

\section{Materials and Methods}

\section{Location and time}

The experiment was conducted for a period of 98 days in three coastal villages viz. Noakhali mouga, Ewazbalia and Karomuliah of Noakhali district in Bangladesh.

\section{Source of birds}

A total of one hundred and seventy four one day-old ducklings of three genotypes viz. Muscovy, Pekin and Desi white were procured from Central Duck Breeding Farm, Narayangonj, Dhaka, Bangladesh. The average weights of the day-old ducklings were $52.43 \mathrm{~g}, 47.25 \mathrm{~g}$ and 33.38 or Muscovy, Pekin and Desi white, respectively.

\section{Experimental design and treatments}

The day-old ducklings of each genotype were assigned at random in two feeding regimes (control and supplemented) in a $2 \times 3$ 
(genotypes) factorial experiment with 3 replicates in each feeding regime. Each replicate consisted of 7, 10 and 12 ducklings for Muscovy, Pekin and Desi white, respectively. The birds of control group received feed only from scavenging and the birds of supplemented groups received concentrated mixture in addition to normal scavenging.

\section{Housing, feeding and management}

All the ducklings were brooded for $0-14$ days. At the age of 15 days the ducklings were transferred to bamboo houses with $0.14 \mathrm{~m}^{2}$ floor space for each bird. The bamboo house was kept in a place adjacent to the farmer's dwelling house where proper ventilation was maintained. All ducklings were vaccinated against Duck Plague and Duck Cholera. The experimental birds were allowed to scavenge freely in the natural water body from 8.00 to 17.00 hours daily. In addition to scavenging feed, the birds belonging to supplementary group received different amounts of concentrate mixture composed of $50 \%$ rice polish $30 \%$ broken rice and $20 \%$ wheat bran in the form of wet mash.

Supplemental feeds were given @10g in the first week which was further increased@ $10 \mathrm{~g}$ in each week until 8 weeks and thereafter $80 \mathrm{~g}$ of wet mash feed was supplied to the birds up to $14^{\text {th }}$ week of age. The supplemental feeds were divided into two equal portions and were given twice daily (7.30 A.M. and at 5.30 P.M.). Feeds were supplied in the plastic bowls and the bowls were cleaned properly before each feeding time. Proper care and management practices were followed by the farmers throughout the experimental period under the supervision of researcher. The ingredient, chemical composition and energy value of supplied feed are shown in Table 1.

Table 1. Ingredient and chemical composition and energy value of the mash feed $(\mathrm{kg} / 100 \mathrm{~kg})$

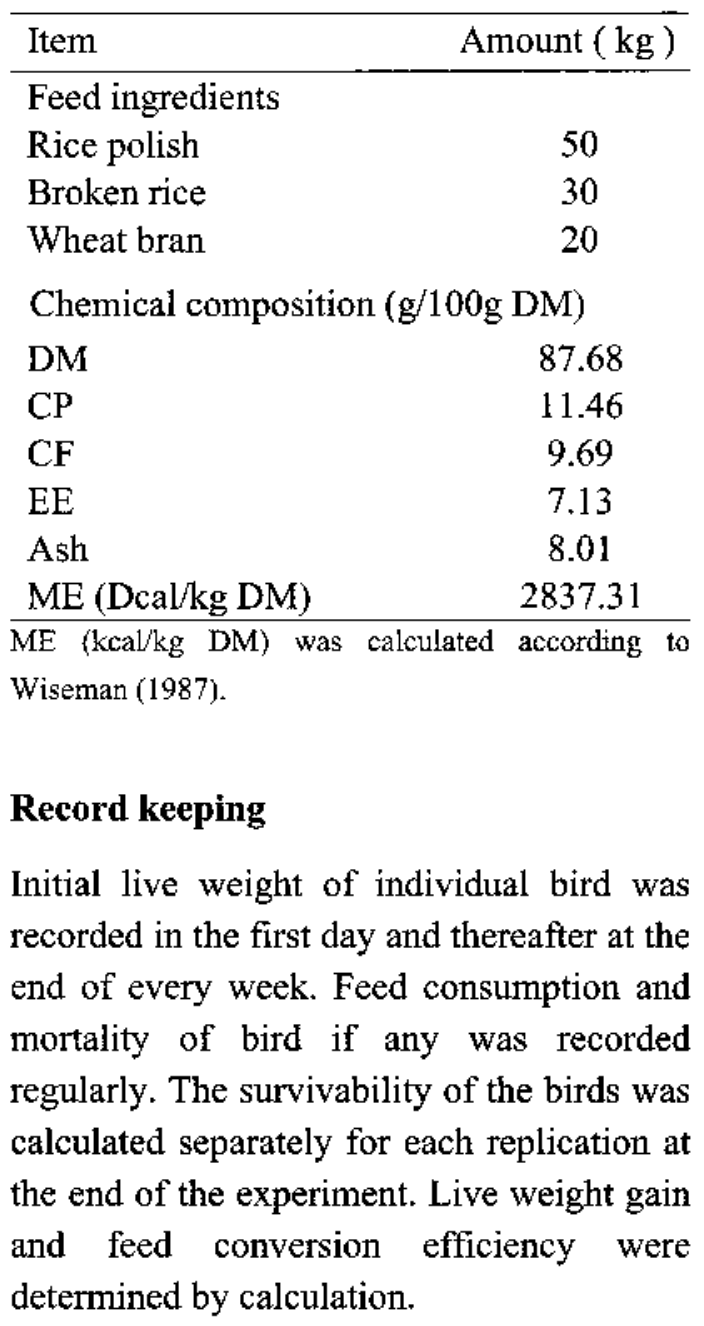




\section{Chemical analysis}

Feed ingredients used for supplemental feeding were analyzed for proximate components following the methods of AOAC (2004). All analyses were performed in the animal Nutrition Laboratory, Bangladesh Agricultural University Mymensingh.

\section{Statistical analysis}

Data collected and calculated for different variables were subjected to analysis of variance in accordance with the procedures of $(2 \times 3)$ factorial experiment in a randomized block design (Steel et al., 1997) using a MSTAT-C statistical package.

\section{Results and Discussion}

\section{Live weight}

Growth performance of different genotypes of ducklings is shown in Table 2. It is evident from the Table 2 that there was a wide variation in live weight among genotypes which ranged between 33 and $52 \mathrm{~g}$ on day o, 450 and $1485 \mathrm{~g}$ on 6 week and 676 and $2285 \mathrm{~g}$ on $10^{\text {th }}$ weeks and the difference for genotypes, feed and interaction of genotype and feed was significant $(\mathrm{P}<0.01)$. The final live weight of the birds at $14^{\text {th }}$ weeks of age also differed significantly $(\mathbf{P}<0.01)$ among the different genotypes of birds. In this experiment, highest live weight was found in Muscovy ( $2.7 \mathrm{~kg}$ ) followed by Pekin $(2.5 \mathrm{~kg})$ and the lowest live weight was found in Desi white $(1.6 \mathrm{~kg})$ at 98 days of age for supplemented group. In contrast, live weight for Muscovy, Pekin and Desi was $1.52 \mathrm{~kg}$,
$1.44 \mathrm{~kg}$ and $0.80 \mathrm{~kg}$, respectively for birds reared by only scavenging. Superiority of Muscovy breed over Pekin and Desi white might be due to genetic potentiality of Muscovy breed as a good forager. At $6^{\text {th }}$ week of age, the live weight of Muscovy was aiso highest. This trend in the growth of Muscovy was maintained throughout the experimental periods and at the end of experiment at $14^{\text {th }}$ week of age, birds of this genotype in control group weighed $1.5 \mathrm{~kg}$ in comparison with $2.7 \mathrm{~kg}$ in supplemental group. Bochno et al., (1992) found that Muscovy ducks had higher final live weight than Pekin which corresponds well with the present findings. Brewster, (1976) in an experiment with Muscovy and Pekin ducklings observed that Muscovy grew more rapidly, had a higher feed consumption and converted feed to live weight more efficiently than Pekin $(\mathrm{P}<0.05)$. Similarly, Kochish (1988) observed that Pekin ducks were inferior to Muscovy ducks for relative growth rate, meat yield and livability. Yeong (1986) compared the growth performance of Desi with white Pekin ducks and showed that Pekin had higher live weight than desi ducks and feed supplemented birds showed more weight gain than the unsupplemented ducks in both genotypes which are in well agreement with the present findings. In another experiment, Yeong and Faizah (1981) observed that local ducks gained less live weight compared to the Pekin ducks.

\section{Live weight gain}

Table 2 shows that highest daily live weight gain was obtained from Muscovy (2717 g), intermediate in Pekin (2578 g) and the lowest 
Table 2. Growth performance of different genotypes of ducklings at 6,10 and 14 weeks of age

\begin{tabular}{|c|c|c|c|c|c|c|c|c|c|c|}
\hline \multirow[b]{2}{*}{ Parameters } & \multirow{2}{*}{$\begin{array}{l}\text { Age in } \\
\text { weeks }\end{array}$} & \multicolumn{2}{|c|}{ Muscovy } & \multicolumn{2}{|c|}{ Pekin } & \multicolumn{2}{|c|}{ Desí } & \multicolumn{3}{|c|}{ SED and level of significance } \\
\hline & & Control & Supple & $\overline{\text { Control }}$ & Supple & Control & Supple & $\underset{(G)}{\text { Genotype }}$ & $\begin{array}{l}\text { es Feed } \\
\text { (F) }\end{array}$ & $\mathrm{G} \times \mathrm{F}$ \\
\hline \multirow{2}{*}{$\begin{array}{l}\text { Day-old live } \\
\text { weight } \\
\text { (g/duckling) }\end{array}$} & od & $52.14^{\mathrm{ab}}$ & $52.71^{\mathrm{a}}$ & $47.17^{\mathrm{b}}$ & $47.33^{\mathrm{b}}$ & $33.20^{\mathrm{c}}$ & $33.55^{\mathrm{c}}$ & $1.618^{* * *}$ & $1.32 \mathrm{I}^{\mathrm{ns}}$ & $2.289^{*}$ \\
\hline & 6 & $745.14^{\mathrm{cd}}$ & $1485.67^{\mathrm{a}}$ & $708.67^{\mathrm{d}}$ & $1345.67^{b}$ & $450.33^{\mathrm{e}}$ & $810.67^{\mathrm{c}}$ & $23.488^{* *}$ & $19.178^{* *}$ & $33.218^{* * *}$ \\
\hline \multirow{3}{*}{$\begin{array}{l}\text { Live weight } \\
\text { (g/bird) }\end{array}$} & 10 & $1202.33^{\mathrm{cd}}$ & $2285.00^{\mathrm{a}}$ & $1145.67^{\mathrm{d}}$ & $2125.67^{b}$ & $676.00^{\mathrm{e}}$ & $1325.67^{\mathrm{c}}$ & c $21.021^{* *}$ & $17.163^{\text {** }}$ & $29.73^{* *}$ \\
\hline & 14 & $1520.67^{\mathrm{d}}$ & $2717.00^{\mathrm{a}}$ & $1440.67^{d}$ & $2578.67^{b}$ & $802.33^{\mathrm{e}}$ & $1650.67^{\mathrm{e}}$ & c $25.671^{* *}$ & $20.960^{* *}$ & $36.304^{* *}$ \\
\hline & 6 & $16.50^{d}$ & $34.11^{\mathrm{a}}$ & $15.75^{\mathrm{d}}$ & $30.9 \mathrm{I}^{\mathrm{b}}$ & $9.93^{\mathrm{e}}$ & $18.50^{\mathrm{c}}$ & $23.246^{* *}$ & $18.980^{* *}$ & $32.875^{* *}$ \\
\hline \multirow{3}{*}{$\begin{array}{l}\text { Live weight } \\
\text { gain }(\mathrm{g} / \mathrm{b} / \mathrm{d})\end{array}$} & 10 & $16.43^{\mathrm{d}}$ & $31.88^{\mathrm{a}}$ & $15.69^{\mathrm{d}}$ & $29.69^{\mathrm{b}}$ & $9.18^{\mathrm{e}}$ & $18.45^{\mathrm{c}}$ & $20.753^{* *}$ & $16.945^{* *}$ & $29.349^{* *}$ \\
\hline & 14 & $14.98^{\mathrm{c}}$ & $27.19^{\mathrm{a}}$ & $14.22^{\mathrm{c}}$ & $25.83^{\mathrm{a}}$ & $7.85^{\mathrm{d}}$ & $16.50^{\mathrm{b}}$ & $46.694^{* *}$ & $38.125^{* 7}$ & $66.036^{*}$ \\
\hline & 6 & - & 1.98 & 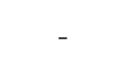 & 2.16 & - & 3.63 & $1.825^{* * *}$ & $1.490^{\mathrm{ns}}$ & $2.582^{\mathrm{ns}}$ \\
\hline \multirow{3}{*}{$\begin{array}{l}\text { Feed } \\
\text { conversion } \\
\text { ratio }\end{array}$} & 10 & - & 3.18 & - & 3.42 & - & 5.47 & $1.830^{* *}$ & $1.187^{\mathrm{ns}}$ & $2.580^{\mathrm{ns}}$ \\
\hline & 14 & - & 4.34 & - & 4.56 & - & 7.13 & $1.047^{* *}$ & $1.492^{\mathrm{nS}}$ & $2.585^{\mathrm{ns}}$ \\
\hline & 6 & $90.47^{b}$ & $95.24^{\mathrm{a}}$ & $86.67^{c}$ & $93.33^{\mathrm{ab}}$ & $83.33^{d}$ & $91.67^{b}$ & $1.047^{* *}$ & $0.854^{* *}$ & $1.480^{* *}$ \\
\hline \multirow{2}{*}{$\begin{array}{c}\text { survivability } \\
(\%)\end{array}$} & $10^{\circ}$ & $90.47^{\text {ab }}$ & $95.24^{\mathrm{a}}$ & $86.67^{\mathrm{ab}}$ & $93.33^{\mathrm{ab}}$ & $83.33^{\mathrm{b}}$ & $91.67^{\mathrm{ab}}$ & $2.958^{\text {ns }}$ & $2.415^{*}$ & $4.183^{\mathrm{NS}}$ \\
\hline & 14 & $90.47^{\mathrm{ab}}$ & $95.24^{a}$ & $86.67^{\mathrm{bc}}$ & $93.33^{\mathrm{a}}$ & $83.33^{\mathrm{c}}$ & $91.67^{\mathrm{ab}}$ & $1.522^{*}$ & $1.243^{* *}$ & $2.153^{\mathrm{NS}}$ \\
\hline
\end{tabular}

Figures with different superscripts in a row differ significantly, ${ }^{*}(\mathrm{P}<0.05) * *(\mathrm{P}<0.01)$

in Desi white $(1650 \mathrm{~g})$ for supplemented group. Similar trend in live weight gain was observed for different genotypes when allowed for scavenging only. Bochno et al. (1992) and Brewster (1976) observed higher live weight gain in Muscovy ducklings as compared to Pekin which agreed well with the result of this study. In the present study ducks that belonged to supplementation group showed significantly $(P<0.05)$ higher growth rate than those of control group irrespective of breed and age. In the present study, the highest growth rate was found in all the breeds during 6 weeks of age but there after the live weight was increasedwith a dccreasing rate which was similar with the observation of Kamar (1962). The results obtained from this study are in well agreement with the findings of several authors (Bagot and Karunajeewa, 1978; Yeong and Faizah, 1981; Bochno et al., 1992, Brewster, 1976 and Dong et. al., 1996).

\section{Feed conversion ratio}

Muscovy duck showed the best conversion ratio of $1.98,3.18$ and 4.34 against the poorest feed conversion of $3.63,5.47$ and 7.13 in Desi white at 6,10 and 14 weeks of age, respectively (Table 2). Brewster (1976) also found best feed conversion efficiency in Muscovy ducks than for Pekin at all ages $(\mathrm{P}<0.05)$. Pekin ducks were also superior to 
Table 3. Cost of production and profit margin of different genotypes of ducklings at 6, 10 and 14 weeks of age

\begin{tabular}{|c|c|c|c|c|c|c|c|c|c|c|}
\hline \multirow[t]{2}{*}{ Parameters } & \multirow{2}{*}{$\begin{array}{l}\text { Age in } \\
\text { weeks }\end{array}$} & \multicolumn{2}{|c|}{ Muscovy } & \multicolumn{2}{|c|}{ Pekin } & \multicolumn{2}{|c|}{ Desi } & \multicolumn{3}{|c|}{ SED and level of significance } \\
\hline & & Control & $\overline{\text { Supple }}$ & Control & Supple & Control & Supple & $\begin{array}{c}\text { Genotypes } \\
(\mathrm{G})\end{array}$ & $\begin{array}{c}\text { Feed } \\
\text { (F) }\end{array}$ & $\mathrm{G} \times \mathrm{F}$ \\
\hline \multirow{2}{*}{$\begin{array}{l}\text { Cost of day- } \\
\text { old duckling }\end{array}$} & - & 14.0 & 14.0 & 14.0 & $1 \overline{4} .0$ & 12.0 & 12.0 & \multirow{3}{*}{$0.286^{* *}$} & \multirow{3}{*}{$0.234^{\mathrm{NS}}$} & \\
\hline & - & - & - & - & - & - & - & & & $0.405^{\mathrm{NSS}}$ \\
\hline \multirow{4}{*}{$\begin{array}{l}\text { Feed cost } \\
\text { (Tk) }\end{array}$} & - & - & - & - & - & - & - & & & \\
\hline & 6 & - & 11.76 & - & 11.76 & - & 11.76 & \multirow{3}{*}{$0.465^{\mathrm{NS}}$} & \multirow{3}{*}{$0.346^{* *}$} & \\
\hline & 10 & - & 29.12 & - & 29.12 & - & 29.12 & & & $0.600^{* *}$ \\
\hline & 14 & - & 47.04 & - & 47.04 & - & 47.04 & & & \\
\hline \multirow{3}{*}{$\begin{array}{l}\text { Medicine and } \\
\text { vaccines } \\
\text { (Tk) }\end{array}$} & 6 & 2.45 & 2.45 & 2.45 & 2.45 & 2.45 & 2.45 & \multirow{3}{*}{$0.143^{\mathrm{NS}}$} & \multirow{3}{*}{$0.117^{\mathrm{NS}}$} & \\
\hline & 10 & 3.50 & 3.50 & 3.50 & 3.50 & 3.50 & 3.50 & & & $0.203^{\mathrm{NS}}$ \\
\hline & 14 & 3.50 & 3.50 & 3.50 & 3.50 & 3.50 & 3.50 & & & \\
\hline \multirow{3}{*}{$\begin{array}{l}\text { Miscellaneous } \\
\text { (Tk) }\end{array}$} & 6 & 3.0 & 3.0 & 3.0 & 3.0 & 3.0 & 3.0 & \multirow{3}{*}{$0.316^{\mathrm{NS}}$} & \multirow{3}{*}{$0.025^{\mathrm{NS}}$} & \\
\hline & 10 & 3.0 & 3.0 & 3.0 & 3.0 & 3.0 & 3.0 & & & $0.044^{\mathrm{NS}}$ \\
\hline & 14 & 3.0 & 3.0 & 3.0 & 3.0 & 3.0 & 3.0 & & & \\
\hline \multirow{3}{*}{$\begin{array}{l}\text { Total cost } \\
\text { (Tk) }\end{array}$} & 6 & 19.45 & 31.21 & 19.45 & 31.21 & 17.45 & 29.21 & \multirow{3}{*}{$0.644^{*}$} & \multirow{3}{*}{$0.526^{* *}$} & \\
\hline & 10 & 20.50 & 49.62 & 20.50 & 49.62 & 18.50 & 47.62 & & & $0.91]^{* *}$ \\
\hline & 14 & 20.50 & 67.54 & 20.50 & 67.54 & 18.50 & 65.54 & & & \\
\hline \multirow{3}{*}{$\begin{array}{l}\text { Total income } \\
\text { (Tk) }\end{array}$} & 6 & 37.25 & 74.25 & 35.40 & 67.25 & 22.50 & 40.50 & \multirow{3}{*}{$1.03^{* k *}$} & \multirow{3}{*}{$0.841^{* *}$} & \\
\hline & 10 & 60.10 & 114.25 & 57.25 & 106.25 & 33.80 & 66.25 & & & $1.46^{* *}$ \\
\hline & 14 & 76.00 & 135.85 & 72.00 & 128.90 & 40.10 & 82.50 & & & \\
\hline \multirow{3}{*}{$\begin{array}{l}\text { Profit margin } \\
\text { (Tk) }\end{array}$} & 6 & 17.80 & 43.04 & 15.95 & 36.04 & 5.05 & 11.29 & \multirow{3}{*}{$1.88^{* *}$} & \multirow{3}{*}{$1.54^{* *}$} & \multirow{3}{*}{$2.67^{\neq *}$} \\
\hline & 10 & 3960 & 64.63 & 36.75 & 56.63 & 15.30 & 18.63 & & & \\
\hline & 14 & 55.50 & 68.31 & 51.50 & 61.36 & 21.60 & 16.96 & & & \\
\hline \multirow{3}{*}{$\begin{array}{l}\text { Cost benefit } \\
\text { ratio } \\
(\mathrm{Tk})^{\prime}\end{array}$} & 6 & 1.92 & 2.38 & 1.82 & 2.15 & 1.29 & 1.38 & \multirow{3}{*}{$0.036^{* *}$} & \multirow{3}{*}{$0.029^{* *}$} & \\
\hline & 10 & 2.93 & 2.30 & 2.79 & 2.14 & 1.83 & 1.39 & & & $0.051^{*}$ \\
\hline & 14 & 3.70 & 2.01 & 3.51 & 1.91 & 2.17 & 1.26 & & & \\
\hline
\end{tabular}

Total income was determined using live weight of ducks $@$ Th, $50 / \mathrm{kg}$ live weight. ** $\overline{\mathrm{p}}<0.01$; $^{*} \mathrm{p}<0.05$ 
Desi ducks in terms of feed conversion efficiency which was similar to the observation of Yeong (1986) and Yeong and Faizah, (1981). The results of the percent study are in close association with the findings of Hamid et al., (1988).

\section{Survivability}

No significant variation $(\mathrm{P}>0.05$ was observed on the survivability rate of different genotypes of ducklings (Table 2). The percent survivability up to 14 weeks of age was $95.24,93.33$ and 91.67 for Muscovy, Pekin and Desi white, respectively, in case of supplemented group. In control group, the percent survivability was $90.47,86.67$ and 83.33 for Muscovy, Pekin and Desi white, respectively. The percent surviyability found in this experiment was slightly lower than the findings of George et al., (1981), Teh et al., (1986), Yeong and Faizah, (1981) and Bhuiyan et al., (2002). The lowest survivability in Desi ducks were observed by Huque and Hossain, (1991) which is in agreement with the present findings.

\section{Cost of production and profit margin}

The various components of expenditure for rearing ducks at 6,10 and 14 weeks of age and profit margin have been presented in Table 3. It is evident from the Table that total rearing cost of different genotypes of ducks stands between Tk.17.45 and 67.54. The highest rearing cost was observed in supplemented group (Tk. 67.54) and the lowest in control group (Tk.17.45) where ducks were maintained only by scavenging without any supplemental feeding. The weight gain of ducks differed significantly among genotypes and there was a great variation in determining the income of ducks which ranged between Tk 82.50 and 135.85 at 14 weeks age. Muscovy ducks has attained the maximum profit margin in comparison to other genotypes. The feed cost had the maximum contribution to the total cost of production. The feed cost increased with advancement of age due to more consumption of feed. Similar observation was aiso supported by Kahlon and Dwivedi, (1965) and Card and Neshiem, (1972). Feed of duck is one of most important factors affecting the profitability of production system (Ali and Islam, 1995). Profit margin was lowest in Desi ducks maintained only by scavenging and highest in Muscovy reared by supplemental feeding of $60 \mathrm{~g}$ concentrate mixture daily in addition to scavenging. As the live weight of ducklings were significantly highest in Muscovy than that of Pekin and Desi duck which increased profit margin in Muscovy ducks. Similar trend was found while calculating cost benefit ratio which was 2.38 for Muscovy, 2.15 for Pekin and 1.38 for Desi at 6 weeks of age with supplementary feeding. Although the cost benefit ratio of different genotypes of duckling at 10 and 14 weeks of age was higher in unsupplemented group than that of supplemented group but Muscovy ducklings have attained the maximum cost benefit ratio (2.38) at 6 weeks of age. The profit margin of the birds differed significantly $(\mathrm{P}<0.01)$ among the different genotypes of birds and feeding regimes. The genotype and feed effect were significant $(P<0.05)$ for cost benefit ratio. 


\section{Conclusions}

Genotypes of ducklings and their age at slaughter must be taken into consideration for raising ducks for meat production considering the growth performance and cost of production. Muscovy ducklings showed superiority to all other ducklings and it may concluded that Muscovy, ducklings could be profitably reared as meat producing bird through supplementary feeding of $60 \mathrm{~g}$ concentrate mixture daily under scavenging system of rearing in low laying coastal areas of Bangladesh and should be marketed at 6 weeks of age.

\section{Acknowledgement}

The author acknowledges the financial assistance provided by DANIDA-DLS through Smallholder Livestock Development Project-2 (SLDP-2) program in order to carry out this research work and the farmers of Noakhali district are also acknowledged.

\section{References}

Ahmed, S. 1986. Duck production in Bangladesh. In: Duck Production Science and World Practice. Farrell. D. J. and Stapleton, P.(Ed.), University of New England, Armidale, Australia, 342-350pp.

Ali, M.A. and Islam, M.A. 1995. The performance of Khaki Campbell (KC), Zending ( $Z$ ) and $\mathrm{KC} \mathrm{X} \mathrm{Z} \mathrm{ducks} \mathrm{in} \mathrm{integrated} \mathrm{duck-cum-fish}$ farming system. Bangladesh Journal of Animal Science, 24 (1-2): 185-193.
AOAC. 2004. Association of Official Agricultural Chemists. Official Methods of Analysis. Washington. D. C.

B.B.S. 2010. Bangladesh Bureau of Statistics. Report of the household income and expenditur survey 2010. Statistics Division, Ministry of Planning, Dhaka, $48 \mathrm{p}$.

Bagot, I. and Karunajeewa. H. 1978. The effect of strain, sex and diet on growth and carcass characteristics of meat type ducks. Australian Journal of Experimental Agriculture and Animal Husbandry, 18: 527-532.

Bhuiyan, M.M., Islam M.R, and Khan M.A.H.. 2002. Comparative performance of different breeds of broiler ducks under farmer's condition at FSRD site Palima, Tangail. Bangladesh Journal of Training and Development, 15 (1 \& 2): 107-111.

Bochno, R., Lewczuk A. and Wawro. E. 1992. Comparison of growth and feed conversion efficiency of Musk and Pekin ducks. Zootechnica, 37: 121-130.

Brewster, R. 1976. Growth of Muscovy and Pekin ducklings in Australia. In proceedings of the First Australian Poultry and Stock Feed Convention, 2: 357-362.

Card, L.E. and Nesheim. M.C. 1972. Poultry production. 2nd ed., Philadelphia, U.S.A.

Dong, N.T.K., Ogle B. and Preston. T.R. 1996. Effect of level of local supplements for fattening Muscovy ducks by poor farmers in remote villages in Mekong delta of Vietnam. Livestock Research for Rural Development. 9 (1): 96-112. 
Dong, N.T.K. and Phuoc. T.H. 1994. Haematological parameters of the local, the French and crosses of French and local Muscovy ducks in Mekong Delta of Vietnam. Conference of Animal Husbandry and Veterinary Medicine in May, 1994. Faculty of Animal Husbandry and Veterinary Medicine, University of Cantho.

George, R.P., Ramakrishnan, A., Unni A.K.K. and G.R. Nair, 1981. Studies on certain economic traits of Deshi ducks. 2. Growth of duckling. Indian Journal of Poultry Science, 16 (1): 44-50.

Hamid, M.A., Chowdhury S.M.R.K. and Chowdhury. S.D. 1988. A comparative study of the performance of growing ducklings of Khaki Campbell, Indian Runner, Indigenous ducks under farm conditions. Indian Journal of Poultry Science, 23: 118-121.

Hoque K.S., Sárker, M.S.K., Huque Q.M.E. and Islam M.N. 2001. Duck production in the Sylhet basin of Bangladesh- Prospects and problems. Paper presented in the seminar and international poultry show organized by the World's Poultry Science AssociationBangladesh Branch at IDB Bhaban, February 16-17, 40-5l pp.

Huque Q.M.E. and Hossain. M.J. 1991. Production potentiality of ducks of three genotypes under scavenging system of management. Bangladesh Journal of Animal Science, 20 (1 \& 2): 119-122.

Kahlon, A.S. and Dwivedi, H.N. 1965. A study of seven poultry farms in Punjab. Agricultuse Situation in India, 19 (9): 877-879.

Kamar, ' G.A.R. 1962. Growth of various breeds of ducks under Egyptian condition. Poultry Science, 41 (4): 1344-1346.
Khan, A.G. 1983. Improvement of Desi ducks -part 2.Poultry Adviser, 16:67-78.

Klemn, R. and Pingel, H. 1992. Selection for improved fertility in crossing of Muscovy ducks with Pekin ducks. In proceedings, $9^{\text {th }}$ International Symposium on Waterfowl, World Poultry Association, 121-123pp.

Kochish, I.I. 1988. Evaluation of Pekin and Muscovy ducks for growth rate, meat production and reproductive traits. Animal Breeding Abstracts, 57 (5): 458.

Phuoc, T.H., Men B.X. and Dong. N.T.K. 1994. A study of performance of local Muscovy ducks in MekongDelta of Vietnam. Sciences and Techniques, University of Cantho, Mekong Delta of Vietnam.

Steel, R.G.D., Torrie J.H. and Dickey, D.A. 1997. Principles and procedure of statisticsA Biometrical Approach. 3rd ed. McGrawHill Co., Inc., New York and London. 139-177pp.

Teh, E.S., Sim K.L. and Chong, Y. 1986. Comparative performance of seven commercial strains of Pekin meat duck. Singapore Journal of Primary Industries, 14 (1): $1-10$.

Wiseman, J. 1987. Feeding of non-ruminant livestock.9-13 pp.

Yeong, S.W. 1986. Utilization of local feedstuffs in diets of meat and laying ducks in Malaysia. In: Duck Production Science and World Practice. Farrell, D. J. and Stapleton, P. (Ed.). University of New England, Armidale, Australia, 323-332pp.

Yeong, S.W. and Faizah, M., 1981. A preliminary observation on the performance differences of local and exotic ducks. Proceedings of conference on exotic and crossbred livestock performance in Malaysia. 11-12 September, 332-344pp. 